UDK 343.344:17

https://doi.org/10.18485/fb_ic4hs.2018.4

\title{
NON-LETHAL WEAPONS IN DOMESTIC LAW ENFORCEMENT: SOME LEGAL AND ETHICAL ASPECTS
}

\author{
Adelina TUMBARSKA*
}

\begin{abstract}
The main principle embodied in the concept of non-lethality is the intention of avoiding fatalities and permanent injuries to people and damage to material objects and the environment. Accordingly, non-lethal weapons (NLWs) are designed to produce shortlasting and reversible effects, unlike conventional weapons intended to cause large-scale death and destruction.
\end{abstract}

International law (IL) is a key instrument for NLWs development and use. However, there are significant gaps and ambiguities in IL regulating the use of weapons and international standards with respect to the legitimate use of NLWs in law enforcement (LE), which cast doubt on the use of NLWs. According to international standards, firearms should be used only exceptionally in LE and governments are therefore encouraged to develop and equip LE officials with NLWs. At the same time, existing laws and policies do not sufficiently stimulate the utilization of NLWs' potential as an alternative to deadly weapons.

Despite significant progress in the development and improvement of NLWs, they are not perfect -the potential for undesirable consequences always exists, since their effects depend on many factors i.e. zero lethality is a goal, not a guarantee. However, problems lie predominantly in the way NLWs are used rather than in the technology itself. The use of NLWs is sometimes untimely, unnecessary or improper, giving grounds for considerable public disapproval.

NLWs have been used in LE all over the world since the 1960s. The interest in their military applications, declared in the early 1990s, initiated extensive debates involving scientists and experts from various fields, politicians, human rights activists, and citizens. These debates are ongoing and concern all aspects of NLWs - conceptual, political, ethical, legal, medical, technological, strategic, operational, tactical, etc.

This paper represents an effort to briefly address the most important legal and ethical problems and discussions arising from the use of non-lethal weapons in domestic law enforcement, as far as this is possible in 12,000 characters including spaces.

\footnotetext{
* Assistant-Professor, PhD, Institute of Metal Science, Equipment and Technologies, Bulgarian Academy of Sciences (IMSETHAC-BAS), y.toumbarski@ims.bas
} 
Key words: non-lethal weapons (NLWs), law enforcement

\section{INTRODUCTION}

Under International law (IL), each State has obligations to respect, protect, ensure and fulfil human rights (ICRC, 2015), including to ensure that its law enforcement (LE) agencies and officials respect and protect the right to life (Geneva Academy of IHL, 2016). According to international standards, "[e]very effort should be made to exclude the use of firearms." (UN, 1997, Art.3) Governments are encouraged to develop and equip LE officials with weapons "that would allow for a differentiated use of force and firearms", including non-lethal weapons (NLWs). (UN, 1990, Art.2) However, the standards with respect to use of NLWs in LE [and IL regulating the use of weapons as a whole] are outdated or ambiguous in a number of key areas. (Dymond-Bass \& Corney, 2014).

Law enforcement comprises not only domestic peacetime policing but also a number of other functions, such as counter-terrorism, counter-narcotics, border protection, etc. In any situation LE officers must perform their duties in accordance with applicable national and international law, complying with rigorous ethical and professional requirements. The need to manage individuals or groups, when a show of force or voice commands are not sufficient and deadly force is not authorized or preferred, is a difficult aspect of the civil LE. To meet this need, LE institutions are widely applying non-lethal technologies in the continuing efforts to protect lives, including of those attempting to harm LE officers or other citizens.

Non-lethal alternatives to conventional weapons are welcomed by LE officers, as they provide means to control various situations with reduced risk for all persons involved and prevent the escalation of force. However their use is not acceptable to everyone. "Criticism has come from suspects, politicians, activists, and citizens. Arguments include the legitimate concerns for human rights and the potential for abuse" (Penn State University, 2010, p.6-3), even claims that NLWs are unhuman, especially created for torture. These critics are part of a large debate on all aspects of NLWs, initiated by the interest in NLWs military applications declared in the early 1990s.

\section{NON-LETHAL (LESS-LETHAL) WEAPONS CONCEPT}

Intention embodied in the concept of non-lethality is avoiding fatalities and injuries on people and damage to material objects and the environment. Accordingly, non-lethal weapons are designed to produce short-lasting and reversible effects. Since the effect of a NLW depends on many factors (weapon characteristics, user skills, context, targeted object characteristics, etc.), potential for undesirable consequences always exist. Principles underlying the NLWs concept give reason to believe that these weapons are more human and ethically superior than conventional, but ultimately conclusion whether NLWs are more ethical depends on the way they are used.

The concept of NLWs in very complex, therefore finding correct term and formulating correct definition is a difficult task. Much of confusions and controversies surrounding NLWs come from the lack of universally accepted term and definition (Barron, 2008). Yet 
all existing definitions include the compulsory requirement of avoiding death or injuries and no one - assurance of the full absence of lethal effects. 'Non-lethal weapons' is a term introduced in the 1960s. Though even then it was noted that to avoid misconceptions or false expectations in must be borne in mind that 'nonlethal' is relative, not absolute term (Coates, 1970, p.2), this term is still criticized and defined from 'incorrect' to 'intentionally misleading'. Although far from perfect, it clearly expresses the intention of user not to cause damage and is established as the most used one amongst dozens of proposed terms ('less-lethal' is term preferred by LE community in some countries). In the context of civil LE, less-lethal weapons (LLWs) are those "primarily designed to temporarily disable or stop suspects without killing, thereby providing an alternative to lethal force where appropriate. These weapons are 'less lethal' in a literal sense because none can be guaranteed to avoid serious injury or death". (National Security Research, 2003, p.10)

\section{SOME LEGAL AND ETHICAL ASPECTS OF THE NLWS' USE IN DOMESTIC LAW ENFORCEMENT}

NLWs have been used by police over the world since the 1960s as an alternative or addition to police batons and firearms in controlling aggressive crowd behavior. (Davison, 2009) At present LE forces are equipped with a wide range of NLWs used in various operations ranging in character and intensity - from confrontations 'one to one' to largescale organized disorder and violence. Despite the experience gained, the use of certain NLWs can result in unintended outcomes under certain conditions. Research has shown that problems are rather in tactics, procedures, policies, training and use of NLW than in technology itself (Penn University, 2010) - large part of accidents, including amongst users, are due to improper handling. Thereby the Human Rights Council, encouraging states to make NLWs available to their LE officials, also encourages international efforts to regulate and establish protocols for training and use of NLWs. (Geneva Academy, 2016)

Combining the maintenance of public order at meetings with the right to freedom of speech, freedom of dissent and the right to assembly is a serious challenge. (CaseyMaslen, 2014) NLWs with worst reputation in such situations are the kinetic non-lethal munitions and the chemical riot control agents (RCAs), particularly tear gas. Although modern impact munitions has been significantly refined, compared to plastic and rubber bullets that have led to a number of deaths in the past, they still can cause injuries if directed to some parts of the human body or shot at too close distance. RCAs are widely debated, as their use as "method of warfare" is prohibited unlike the use in "law enforcement including domestic riot control purposes". (Chemical Weapons Convention, 1993, Art.II,9,d). In other words, chemical RCAs ,,are lethal enough to fall under the CWC of 1993, but in domestic affairs during times of peace, when human rights law is the applicable legal regime, these same riot control agents are accepted as a riot suppressant against often innocent civilians". (Knoechelmann, 2012, p.1) There are views that partial or radical changes in IL are needed to allow for use of RCAs in armed conflicts (Fidler, 2001), and vice versa - that RCAs should be totally prohibited. The last indicates "lack an 
understanding of the benefits and necessity of RCAs as a tool of protecting public order". (Knoechelmann, 2012, p.34)

Other distaste with NLWs comes from their use on suspects, detainees and prisoners. There are claims that NLWs are used untimely or unnecessarily, "in situations that would have previously been resolved with the use of less force, or even without the use of any force at all". (Coleman, 2012, p.198) Evidences exist that many US police agencies are routinely deploying 'Tasers' to subdue individuals who do not pose a serious danger to themselves or others. (Amnesty International, 2002) Most claims in the US judicial system connected with NLWs are based on the use of 'excessive force' resulting from choice of incorrect weapon/ammunition or its use outside the established guidelines. (Penn University, 2010) Though, "[w] hen used responsibly by well-trained and fully accountable law enforcement officials, LLWs can prevent and minimize deaths and injuries to assailants, suspects and detainees, as well as protect the police and prison officers themselves". (Amnesty, 2015)

Abuses of NLWs by repressive governments are regularly documented by several organizations. Reports expose terrible practices of torture or extraction of information from suspected criminals and dealing with political opponents or non-tolerated religious and social groups applied in some countries. (Bureau of Democracy, 2017) Apart from barbarian methods and tools, torturers rely on more advanced technologies - examples of abuse of 'Tasers', rubber bullets and tear gas are highlighted in a number of Amnesty International and Omega Foundation reports. These institutions call for banning NLWs export to countries where they are used for human rights violations to "back moral responsibility with legal liability". (Wright, 2001, p.223)

Counter-terrorist operations pose great challenges as terrorists are often mixed with citizens, whether hostages or passers-by. Although certain NLWs significantly increase the probability for saving hostages and capturing terrorists alive, their use is perceived in contradictory ways. An emblematic case in this regard is the hostage rescue action in Moscow in 2002. After 2-day siege of the theater, where 40-50 heavy armed Chechen terrorists put bombs and held 916 hostages, Russian spec-forces introduced an anesthetic agent into the ventilation system and then stormed the building. As a result 129 hostages lost their lives (many due to inadequate evacuation and medical care) and all the terrorists were shot. This operation is widely criticized, however although it may seem excessive that $16 \%$ of the hostages died from or after the gas exposure, $84 \%$ survived; "The use of an 'incapacitant' in this setting was a novel courageous attempt at saving the most lives". (Reimann, 2007, p.3a-7). This case provoked discussions on incapacitating chemical agents (ICAs) in general, and on the legality of their use in LE. The right conclusion seems to be that use of ICAs "in contexts where neither individual dosage nor the exposure conditions can be controlled is legitimate only in extreme situations". (Fidler, 2005) Killing the incapacitated terrorists, instead of being arrested and handed to justice, brings to the fore a very important problem - about the use of NLWs for facilitating the use of deadly force.

Many official documents state that NLWs are developed to provide LE with an alternative to lethal force, however policy and practice cast doubt on these allegations - the 
authorities who control the police use of NLWs are often too cautious to use them as a substitute for lethal weapons. (Davison, 2009) Other documents clearly show the intention that NLWs "should never be considered a replacement for the legal use of lethal force" rather LE officers should use them "as an instrument of force continuum between show of force or verbal commands and deadly force". (National Security Research, 2003, p. 10) Indeed, although LE officers are required to employ only 'reasonable' or 'proportionate' levels of force, there is no legal obligation of using NLWs first before resorting to lethal weapons. Some suppose that "the law may well develop in the direction of requiring them to proceed with the less deadly means first". (Koplow, 2005, p.796) However, given the resistance of some states to the adoption of international treaties restricting the use of lethal weapons, this is unlikely to happen.

\section{CONCLUSION}

While NLWs conception gives reasons to believe that they are more human and ethical than conventional weapons, examples of their use (from involuntary mistakes to deliberate abuse) are constantly emerging and raising doubts about such an assertion. Improving the use of NLWs in LE can be achieved through developing appropriate policies and procedures for use, review and supervision, and creating laws and policies stimulating utilization of the NLWs' potential as an alternative to deadly weapons. Although not perfect, NLWs provide domestic LE authorities with capabilities to apply low levels of force in maintaining law and order and controlling violent situations. Undoubtedly, public debates are necessary to ensure that NLWs are developed and used in accordance with law and ethics. An unbiased and informed discussion would be even more constructive, focusing not only on negatives accumulated over the years but also recognizing the benefits of implementing NLWs.

\section{REFERENCES}

Amnesty International. (2002). Excessive and Lethal Force? Amnesty International's Concerns about Deaths and Ill-Treatment Involving Police Use of Tasers. Amnesty International, Retrieved from https://www.amnestyusa.org/reports/usaexcessive-and-lethal-force-amnesty-internationals-concerns-...

Amnesty International. (2015, April 13). 'Less-lethal' weapons can kill and police misuse them for torture. Retrieved from https://www.amnesty.nl/actueel/less-lethalweapons-can-kill-and-police-misuse-them-for-torture

Barron, B. (Ed.). (2008). Non-Lethal Weapons International Study. Pennsylvania, USA: Penn State Fayette, Retrieved form http://fieldcommand.org/wpcontent/uploads/2013/05/ Penn-State-Intl-NLW-study.pdf

Bureau of Democracy, Human Rights and Labor. (2017). Country Reports on Human Rights Practices. U.S. Department of State. Retrieved from https://www.state.gov/ documents/organization/277207.pdf 
Casey-Maslen, S. (2014). Crowd management, crowd control, and riot control. In S. Casey-Maslen (ed.). Weapons under International Human Rights Law. Cambridge, UK: Cambridge University Press.

Coates, J. (1970). Non-Lethal and Non-destructive Combat in Cities Overseas. Alexandria, USA: Institute for Defense Analyses. Retrieved form http://www.dtic.mil/dtic/tr/ fulltext/u2/745773.pdf

Coleman, S. (2015). Possible Ethical Problems with Military Use of Non-Lethal Weapons. Case Western Reserve Journal of International Law. 47 (1), Issue 1, 185-199.

Convention on the Prohibition of the Development, Production, Stockpiling and Use of Chemical Weapons and on their Destruction. (1993). Geneva, CH. Retrieved form https://treaties.un.org/Pages/ViewDetails.aspx?src=TREATY\&mtdsg_no=XXVI$3 \&$ chapter $=26 \&$ lang $=$ en

Davison, N. (2009). Non-Lethal Weapons. London, UK: Palgrave Macmillan. Retrieved form https://link.springer.com/chapter/10.1057/9780230233980_2

Dymond-Bass, A. \& Corney, N. (2014). The use of 'less-lethal' weapons in law enforcement. In S. Casey-Maslen (ed.). Weapons under International Human Rights Law, Cambridge, UK: Cambridge University Press.

Fidler, D. (2001). 'Non - lethal' weapons and international law: Three perspectives on the future. Medicine, Conflict and Survival. 17(3). 194-206. DOI: 10.1080/13623690108409579.

Fidler, D. (2005) The meaning of Moscow: 'Non-lethal' weapons and international law in the early 21 st century. International Review of the Red Cross, 87(859). 525-552. Retrieved from https://www.icrc.org/eng/assets/files/other/irrc_859_fidler.pdf

Geneva Academy of International Humanitarian Law and Human Rights. (2016). Use of Force in Law Enforcement and the Right to Life: The Role of the Human Rights Council. Academy In-Brief, No 6. Geneva, CH: The Academy. Retrieved from https://www.geneva-academy.ch/joomlatools-files/docman-files/inbrief6_WEB.pdf

International Committee of the Red Cross. (2015). The use of force in law enforcement operations. Geneva, CH: ICRC. Retrieved from https://www.icrc.org/.../the-useof-force-in-law-enforcement-ic...

Knoechelmann, K. (2012). The Legal Paradox of International Chemical Riot Control Regulations. Association for the Promotion of International Humanitarian Law. Retrieved form http://www.alma-ihl.org/opeds/knoechelmannriotcontrolagents 102012

National Security Research. (2003). A Research Guide for Civil Law Enforcement and Corrections, USA: Department of Justice. Retrieved form https://www.ncjrs.gov/pdffiles1/nij/grants/200516.pdf

Penn State University. (2010). Guidebook for Less-Lethal Devices: Planning for, Selecting, and Implementing Technology Solutions. Pennsylvania, USA: WPSTC. 
Reimann, K. (2007). Non-Lethal Technology (NLT) Approaches to Hostage Situations. NATO Research and Technology Organization Report NATO RTO-EN-HFM145. Retrieved from https://www.sto.nato.int/publications/pages/results.aspx?sq=1\&k=nonlethal\%20weapons\&s=Search\%20All\%20STO\%20Reports

United Nations. (1979). Code of Conduct for Law Enforcement Officials. Adopted by United Nations General Assembly resolution 34/169 of 17 December 1979, Retrieved from https://www.ohchr.org/Documents/ProfessionalInterest/codeofconduct.pdf

United Nations. (1990). Basic Principles on the Use of Force and Firearms by Law Enforcement Officials. Adopted by the 8th UN Congress on the Prevention of Crime and the Treatment of Offenders, Havana, Cuba, 27 Aug. to 7 Sept. 1990. Retrieved from https://www.ohchr.org/en/professionalinterest/pages/useofforceandfirearms.aspx

Wright, S. (2001). The role of sub - lethal weapons in human rights abuse. Medicine, Conflict and Survival, 17(3). 221-233. DOI: 10.1080/13623690108409581. 